\title{
The importance of topotypic specimens in revisionary studies of oribatid mites (Acari: Oribatida)
}

\author{
Fabio BERNINI* and Massimo MIGLIORINI \\ Department of Life Sciences, via A. Moro 2, University of Siena, Siena, Italy
}

\begin{abstract}
Taxonomic revisions should comply with certain best practices, one of which is to study topotypic specimens if type specimens are not available. We discuss the example of an oribatid mite, the classical species Carabodes labyrinthicus (Michael 1879), in which topotypes are critical to questions of identity, synonymy, and species status.
\end{abstract}

Key words: Oribatid mite, Carabodes labyrinthicus, taxonomic method, type material, topotype

\section{INTRODUCTION}

Species descriptions and revisions of oribatid mites should comply with certain best practices (Bernini 1979; Bernini and Avanzati 1988; Bernini and Nannelli 1982; Bernini et al. 1988; Cancela da Fonseca 1970; Kagainis 2014; Salomone et al. 1996, 2003), which may be summarized as follows:

1) Essential and indispensable taxonomic practices:

a) availability of a sufficient number of specimens preserved in alcohol

b) accurate descriptions accompanied by explanatory drawings

c) biogeographical and ecological information

2) Highly desirable taxonomic practices:
a) existence and availability of type series
b) availability and thorough studies of juvenile stages
c) SEM pictures
d) molecular analyses
e) variability analyses, biometric statistics

Although these best practices are important, we believe that they are not sufficient to avoid systematic errors. Because types, cotypes, and syntypes are often damaged or in poor condition, when redescriptions are needed, it may be useful to follow Grandjean's (1936) advice to collect samples from type localities (topotypes). Appropriate planning of sampling produces a large

Tetsuo Gotoh and DeMar TAYLOR (eds.), Acarology XIV: Proceedings of the International Congress. Journal of Acarological Society of Japan 25 (Suppl. 1): 1-192.

* Corresponding author: e-mail: fabio.bernini@unisi.it

DOI: 10.2300/acari.25.Suppl_27 
number of specimens and makes it possible to investigate intraspecific variation (Avanzati et al. 2004; Kagainis 2014). Authors are often convinced that oribatid mites have wide distributions, owing to passive dispersal and their great ecological plasticity (Michael 1884). However, in our experience, these mites may have small geographic distributions and limited autoecological traits. It is therefore a good rule to redescribe specimens and perform ecological and molecular analyses only with samples collected at the type locality of a species.

In this paper, we discuss the example of an oribatid species, Carabodes labyrinthicus (Michael 1879), that describes this situation. This example will be described in full detail in a future paper now in preparation.

\section{EXAMINED MATERIALS}

One of us (F. B.) examined specimens of Michael's collection sent by the British Museum of Natural History in London (BMNH). The results of this analysis are summarized as follows:

1) Slides n. 1930.8.25.817-819. These three slides are labeled "sub Carabodes labyrinthicus", corrected to "Carabodes minusculus"; at present, they must be classified as Carabodes willmanni (Bernini, 1975).

2) Slide n. 1930.8.25.595/596 (+1), labeled “sub Tegeocranus marginatus 우 $4 \mathrm{~S}$ ”.

3) Slide n. 1930.8.25.820, labeled "sub Carabodes marginatus, Theydon Bois (Essex), 7/78". Both slides include specimens determined as C. labyrinthicus. The specimen on the latter slide is designated as the lectotypus, as it presumably belongs to the syntype series (the date of preparation is $7 / 78$ !), and it is the unique specimen from one of the localities indicated in Michael (1879), Theydon Bois (Essex, Epping Forest) (recommendation 74E, International Code of Zoological Nomenclature, online).

4) Slides n. 1930.8.25.821-827 are all labeled "sub Carabodes marginatus", but really only slides n. $822,823,824$ and 826 include true C. marginatus; n. 823 is the lectotypus of this species, as stated by K.-H. Forsslund on the slide label.

F. B. examined the specimens classified as C. labyrinthicus in Berlese's collection, kept in the Istituto Sperimentale per la Zoologia Agraria (ISZA) in Florence. They include Carabodes minusculus Berlese, 1923, [tipico, M.te Giovi, Mugello, musco], and other specimens of the same species (Bernini 1970, 1976). Other specimens labeled "sub C. labyrinthicus", from Sondrio and Ghiacciaio dei Forni (Fornai, according to Berlese's original label), must be determined as Carabodes schatzi Bernini, 1976 (Bernini 1970, 1976).

Other Berlesian specimens were analyzed:

1) Slide n. 172/7, containing three specimens from Tiarno (Trentino), labeled "sub Carabodes vermiculatus Berlese, 1916 (tipico)”, but really belonging to C. labyrinthicus (Michael 1879), so C. vermiculatus is therefore a junior synonym of the English species.

2) Slide n. 196/3, labeled "sub Carabodes nepos (?) Hull from Ireland", and sent to Berlese by Halbert. This preparation also contains a specimen belonging to C. labyrinthicus (Bernini 1970).

Moreover, redescriptions and SEM analysis have been based on modern collections of $C$. labyrinthicus (sensu lato) from: 
1) Theydon Bois (Epping Forest), near London, $100 \mathrm{~m}$ a.s.1.; litter and humus under Fagus sylvatica, Ilex sp., and Hedera sp.; 21.07.1985. Leg. F. Bernini.

2) Tiarno di Sopra (Trentino), $800 \mathrm{~m}$ a.s.l.; litter and humus under F. sylvatica and Picea abies near a small stream; 24.09.1990. Leg. M. Migliorini and M. Baratti.

3) La Gomera Island (Canary Archipelago), Garajonay National Park, $1100 \mathrm{~m}$ a.s.l.; litter and humus under Laurus nobilis and Erica arborea; 07.03.1992. Leg. M. Migliorini and A. M. Avanzati.

\section{RESULTS AND DISCUSSION}

A. D. Michael's taxonomic ideas on other carabodid species (Bernini 1970, 1975, 1976, 1979) were somewhat confused. Despite his good description and illustration of Tegeocranus labyrinthicus (Michael 1879), subsequent compilation of the first volume of "British Oribatidae" (Michael 1884) left much to be desired. The illustration of T. labyrinthicus was replaced with one of a completely different species, which would later be named Carabodes willmanni (Bernini 1975), and the redescription was a synthesis of the characters of both species. Was this due to an oversight or did it occur for other reasons? About the same time, Michael discovered other carabodid specimens, all characterized by particular variability, which he presumably assigned to two "great species": Carabodes marginatus, originally described and illustrated by himself (Michael 1884), and C. labyrinthicus, expanding its diagnostic characters with respect to his initial concept (Michael 1879). Events can be reconstructed by analyzing Michael's collection in the BMNH, London. There are, to our knowledge, three slides labeled "Carabodes labyrinthicus", but none of them matches Michael's species; their original labels have been corrected to Carabodes minusculus Berlese, 1923, but actually they are all Carabodes willmanni Bernini, 1975 (Bernini 1975, 1976). Nevertheless, there are at least two specimens of $C$. labyrinthicus in the collection, respectively labeled "Tegeocranus marginatus" and "Carabodes marginatus from Theydon Bois, Essex [Epping Forest, one of the localities listed in the 1879 description], 7/78", without any indication of typus, cotypus or lectotypus. Moreover, other carabodid species, such as Carabodes areolatus Berlese, 1916, and C. chirstlus Mahunka, 1987 (from Blida, Algeria), in Michael's collection are recorded under the label "marginatus".

In the late 19th century, data on the true C. labyrinthicus were completely overlooked, and according to Sellnick \& Forsslund (1953), Luxton (1987) and Subias (2004, updated 2014), this species (or something like it) was proposed under new names by four different authors: Trägårdh (Carabodes marginepunctatus, 1902), Oudemans (Cepheus heimi, 1903), Hull (C. scymnus, 1914) and Berlese (C. vermiculatus, 1916). Misidentification of C. labyrinthicus continued with the description of Carabodes minusculus by Berlese (1923). When Berlese had just published his description of the species, he realized that he had described an almost forgotten species, $C$. labyrinthicus, first described by Michael. Thus, in his personal annotations (in Berlese Acarotheca Register at ISZA, Florence), Berlese synonymized minusculus with labyrinthicus. Finally, Willmann (1928) realized Michael's and his followers' mistake: he restored the earlier concept of C. labyrinthicus (Michael 1879) and combined the illustration of C. labyrinthicus dated 1884 with Berlese's description of C. minusculus. 
For almost 50 years, C. minusculus continued to be cited from various parts of the world and from different environments until Bernini (1970, 1975, 1976), studying Michael's type material and Berlese's specimens of C. minusculus in his collection, realized that the C. minusculus of Willmann and all central European authors was another species, which he named $C$. willmanni.

Precisely redefined on the basis of types and topotypes (Bernini 1976), C. minusculus Berlese proved to have a limited distribution (little more than Italy), and was considered the nominate member of a group of species (at least six in Italy), each of which is distinct in morphological characters, geographical distribution, and ecological preferences. However, the interpretation of C. labyrinthicus was reasonably correct. It was considered taxonomically close to C. minusculus by Sellnick and Forsslund (1953), even if it is morphologically very different in many characters.

The present taxonomic concept of $C$. labyrinthicus is that of a widespread (Holarctic) species with ecological preferences " $\cdots$ different moist acid soils; $\cdots$ moss cushion and tree bark" (Weigmann 2006). Moreover, "It has the most northerly distribution of any Carabodes in the Nearctic zone" (Reeves 1988). The mesic preferences of this species are also confirmed by Italian records: it can be found in the Alps and at the highest altitudes of the peninsular Apennines. A single specimen was also found on Capraia Island (Tuscan Archipelago), an intermediate station on the migration route of birds, which are known to transport oribatid mites (Bernini 1991; Lebedeva and Lebedev 2008; Schatz 1991). The taxonomic diagnosis of $C$. labyrinthicus is easy owing to the many recent descriptions from different countries.

In our opinion, the taxonomic problems stem from overly generalized descriptions that often interpret the same characters in a different way. Apart from the labyrinthine rows of tubercles on the notogastral microsculpture, what are the main diagnostic characters? Which is the most authoritative description? Considering that Carabodes includes known polymorphic species such as C. minusculus and C. marginatus (Bernini 1975, 1976; Avanzati et al. 2004), are we sure that $C$. labyrinthicus is not also a polymorphic species with several phenotypes, each typical of more limited regions and environments? Or is it a member of a cryptic species-group? Lacking a description based on specimens reliably belonging to the typical series, the only way to answer these important questions is to analyze topotypes collected in one of the localities in which Michael found his specimens, viz. Theydon Bois, in Epping Forest, near London.

Specimens from Theydon Bois turned out to be very similar to Michael's (1879) illustration (Fig. 1a-d): Ridges constituted by tubercles on the central notogastral surface "arranged in winding lines leaving narrow depressions between" are more evident than the tubercles themselves (Fig. 1c, d). Another concordant character is the form of the prodorsal surface between the lamellae: a triangle having a semilunar depression in the margin near where it joins the notogaster with areolate microsculpture that in the sagittal portion becomes longitudinal ridges (Fig. 1c). Portions of the body surface (notogaster included) with microsculpturing have tubercles close together in rows, coalescing in a maze-like arrangement. This topotypic phenotype differs from that of most citations for this species. To understand the limits of this apparent intraspecific variation, after the designation of the lectotypus, we needed to carefully review the specimens in Michael's collection, and the different populations attributed to this species collected in various Holarctic regions. For comparison, we analyzed two southern populations, the first collected at Tiarno (Trentino, Italy), the locus typicus of $C$. vermiculatus 

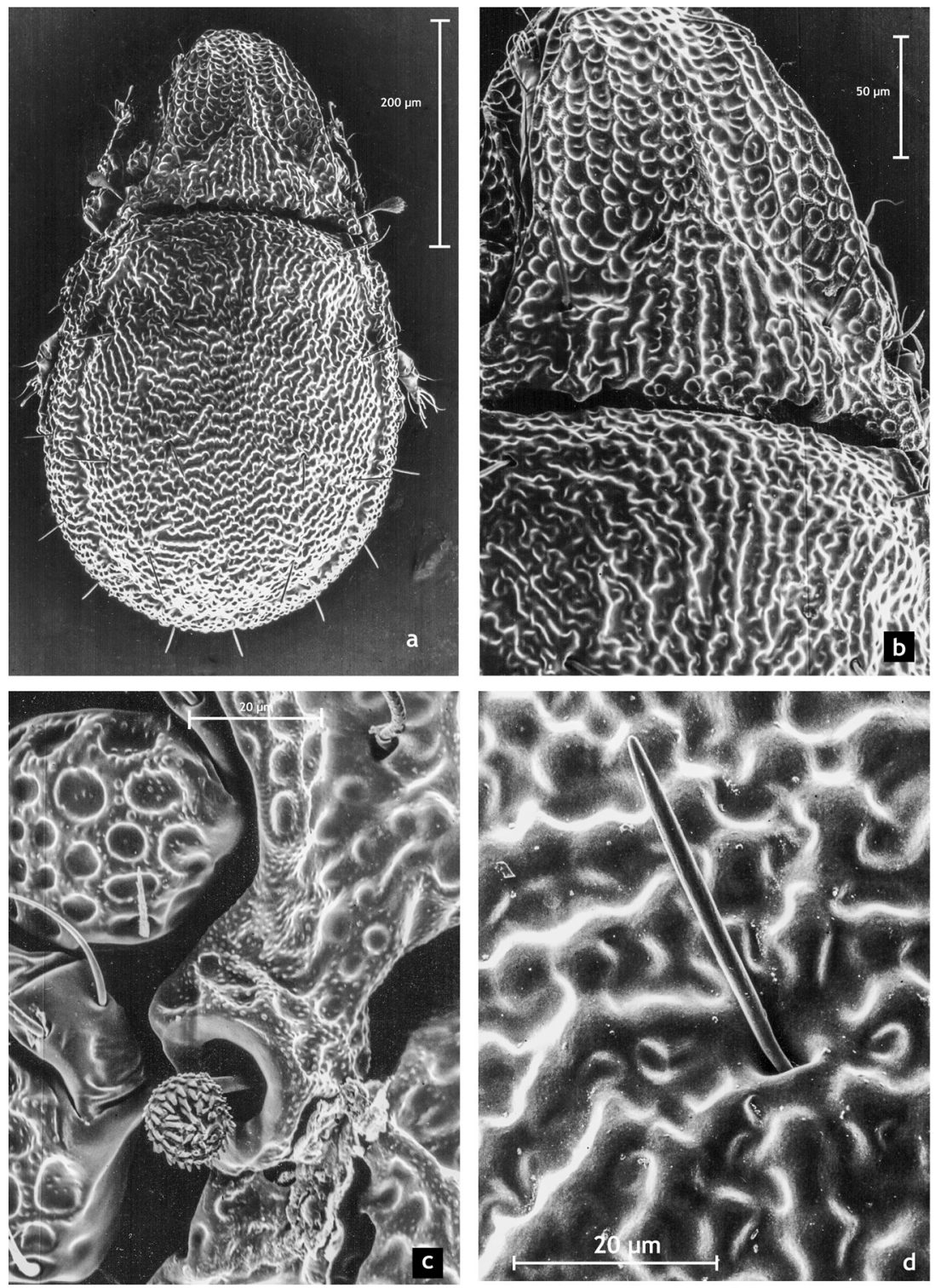

Fig. 1. Carabodes labyrinthicus (Michael 1879) from Theydon Bois, Epping Forest, London. a: Dorsal view of the whole animal; b: detail of the sejugal region in the dorsal view; c: detail of the bothridial region in the dorsal view; d: detail of the dorsal notogastral microsculpture showing a smooth seta.

Berlese, 1916, a junior synonym of C. labyrinthicus (Bernini 1970); the second on La Gomera island (Canary Archipelago). In the Italian population, the microsculpture consists of raised tubercles forming coalesced rows and a "vermiculate" arrangement (Fig. 2a, b), but the other 

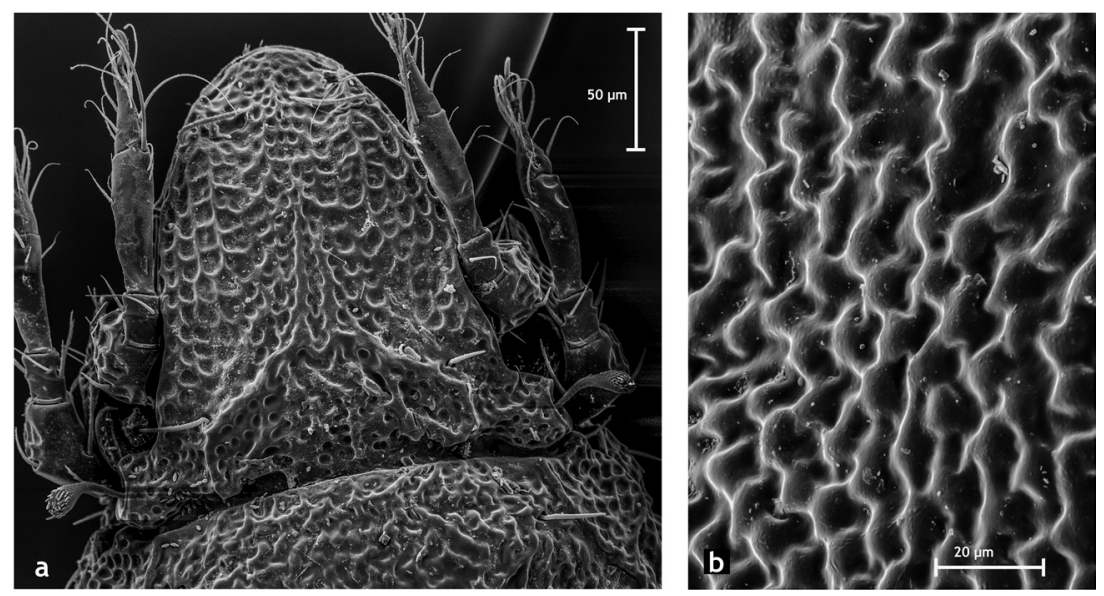

Fig. 2. Carabodes labyrinthicus (Michael 1879) from Tiarno, Trentino, Italy. a: Detail of the dorsosejugal region in the dorsal view; b: detail of the labyrinthine rows of tubercles on the notogastral microsculpture in the dorsal view.
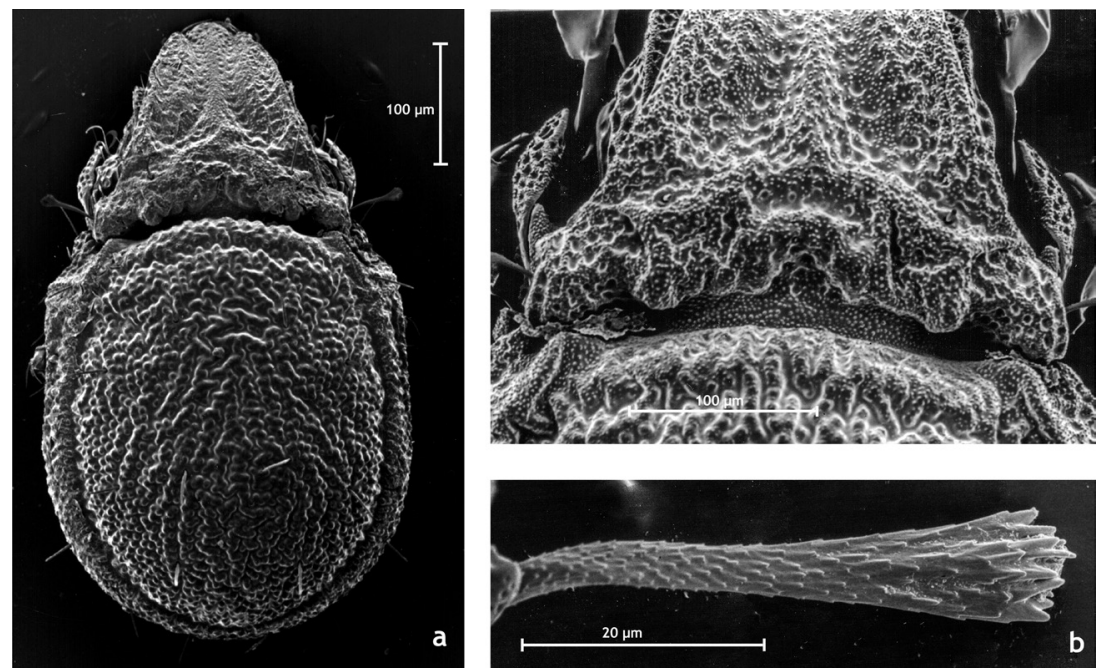

Fig. 3. Carabodes "labyrinthicus" from the Canary Islands. a: Dorsal view of the whole animal; b: detail of the dorsosejugal region in the dorsal view; c: detail of the reverse-conical sensillus.

characters agree with those of the British specimens. In contrast, the Canarian population shows the following differences from labyrinthicus (Figs. $3 \mathrm{a}-\mathrm{c}, 4 \mathrm{a}, \mathrm{b}$ ): (a) notogastral microsculpture consisting mainly of punctuated tubercles, often not coalesced (Figs. $3 \mathrm{a}, 4 \mathrm{a}, \mathrm{b}$ ); (b) outwarddirected sensillus with a reverse-conical head (Fig. 3); (c) basal prodorsal microsculpture neither areolate nor cristate (Fig. 3b); (d) larger dorsosejugal furrow (Fig. 3b); (e) notogastral setae slightly dentate (Fig. 4b). Our interpretation of this population (and others from other Canary islands) is that it may be an undescribed species very close to Michael's taxon, perhaps a member 

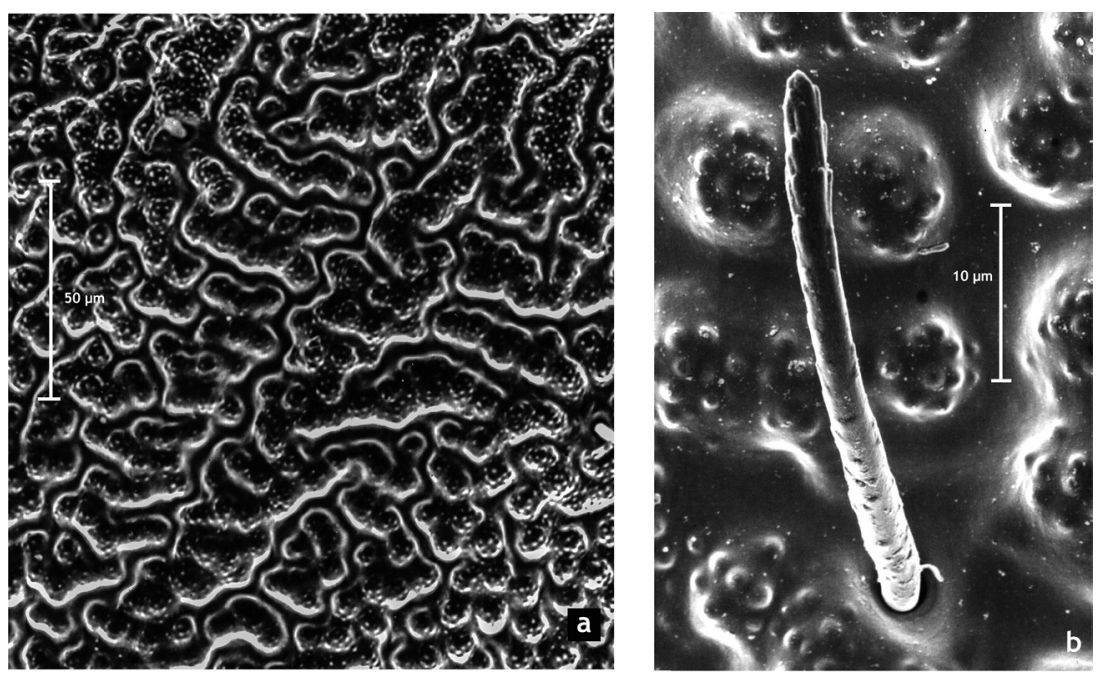

Fig. 4. Carabodes "labyrinthicus" from the Canary Islands. a: Detail of the centrodorsal notogastral microsculpture; b: detail of the dentate notogastral seta and the notogastral punctuated tubercles in the dorsal view.

of a cryptic species group.

A reliable analysis of these issues requires a multidisciplinary approach and teamwork by morphologists, biogeographers, ecologists, molecular biologists, and statisticians.

\section{CONCLUSIONS}

It is evident that the study of topotypic materials not only allows thorough redescriptions, as required by basic taxonomy, but also is indispensable to exploring the variability of diagnostic characters based on large numbers of specimens. In addition, the study of many other populations collected in the distributional (geographic and ecological) range increases our knowledge of species group biology, ecology, and evolutionary history.

\section{ACKNOWLEDGEMENTS}

This study was based largely on specimens kindly sent by Dr. A. S. Baker (Michael's collection, BMNH, London) and Dr. R. Nannelli (Berlese's collection, ISZA, Florence). Other people provided substrate samples or donated specimens used in this study: Prof. H. Schatz, Prof. A. M. Avanzati, and Prof. M. Baratti. We are grateful to all.

\section{REFERENCES}

Avanzati, A. M., N. Salomone, M. Baratti and F. Bernini (2004). Genetic diversity in the Carabodes marginatus species group (Acarida, Oribatida, Carabodidae) as inferred from allozymes. Journal of Natural History, 38: 1927-1940.

Berlese, A. (1923). Centuria sesta di Acari nuovi. Redia, 15: 237-262. 
Bernini, F. (1970) Notulae Oribatologicae II. Gli Oribatei (Acarida) delle Alpi Apuane ( $1^{\circ}$ serie). Lavori della Società Italiana di Biogeografia, n.s. 1: 390-429.

Bernini, F. (1975) Notulae Oribatologicae XII. Una nuova specie di Carabodes affine a C. minusculus Berlese, 1923 (Acarida, Oribatei). Redia, 56: 455.471.

Bernini, F. (1976) Notulae Oribatologicae XIV. Revisione di Carabodes minusculus Berlese, 1923 (Acarida, Oribatei). Redia, 59: 1-49.

Bernini, F. (1979) Considerations on the biogeography and systematics of Oribatid mites. Proceedings of the 4th International Congress of Acarology, Saalfelden, 51-55.

Bernini, F. (1991) Oribatids and insular biogeography. In: Biogeographical Aspects of Insularity. Proceedings of the International Symposium of the Accademia Nazionale dei Lincei, Rome, 1987. Atti dei Convegni Lincei, 85: 23-43.

Bernini, F. and A. M. Avanzati (1988) Taxonomic revision of Steganacarus (Steganacarus) magnus (Nicolet, 1855) (Acarida: Oribatida). Journal of Natural History, 22: 435-464.

Bernini, F., A. M. Avanzati and R. Petrucci (1988) Genetic variation in the soil phthiracarid mite, Steganacarus (S.) magnus (Nicolet, 1855) (Acarida: Oribatida) (Notulae Oribatologicae XL). Zeitschrift fur zoologische Systematik und Evolutionsforschung, 26: 104-113.

Bernini F. and R. Nannelli (1982) Notulae oribatologicae XXVI. Contribution to the knowledge of the genus Cepheus (Acarida, Oribatida) in Italy. Redia, 65: 155-188.

Cancela da Fonseca, J. P. (1970) De la systematique à l'écologie. Quelques problèmes. Acarologia, 12: 23-24.

Grandjean, F. (1936) Les Oribates de Jean Fréderic Hermann et de son père (Arachn. Acar.). Annales de la Societé Entomologique de France, 105: 27-110.

International Code of Zoological Nomenclature, online (access: 26.11.2014)

Kagainis, U. (2014) A morphometric study of oribatid mites (Acari: Oribatida) of the genus Carabodes C. L. Loch, 1835 (Carabodidae) using a confocal laser scanning microscope: an alternative approach to quantitative analysis of various features. Zoomorphology, 133: 227-236.

Lebedeva, N. V. and V. D. Lebedev (2008) Transport of oribatid mites to the polar areas by birds. In: Integrative Acarology. Proceeding of 6th European Congress of the European Association of Acarologists. Bertrand M., Kreiter S., McCoy K. D., Migeon A., Navajas M., Tixier M.-S., Vial L. (eds). Montpellier, 2008, 175-182.

Luxton, M. (1987) The oribatid mites (Acari: Cryptostigmata) of J. E. Hull. Journal of Natural History, 21: 1273-1291.

Michael, A. D. (1879) A contribution to the knowledge of the British Oribatidae. Journal of the Royal Microscopical Society, 2: 225-251.

Michael, A. D. (1884) British Oribatidae. Vol. I. Ray Society, London, pp. 1-336.

Reeves, R. M. (1988) Distribution and habitat comparisons for Carabodes collected from conifer branches with descriptions of brevis Banks and higginsi sp. n. (Acari: Oribatida: Carabodidae). Proceedings of the Entomological Society of Washington, 90: 373-92.

Salomone, N., A. M. Avanzati, M. Baratti and F. Bernini (2003) Genetic and Morphological Analysis of Some European Species of the "coriaceus group" of Carabodes (Acari, Oribatida, Carabodidae) and Description of C. tyrrhenicus sp. nov. Zoologischer Anzeiger, 242: 121-136.

Salomone, N., F. Frati and F. Bernini (1996) Investigation on the taxonomic status of Steganacarus magnus and Steganacarus anomalus (Acari: Oribatida) using mitochondrial DNA sequences. Experimental \& Applied Acarology, 20: 607-615.

Schatz, H. (1991) Arrival and establishment of Acari on oceanic islands. In: Modern Acarology. Proceedings of the VIII International Congress of Acarology, Ceske Budejovice, 1990. Dusbabeck F. and Bukva V. (eds). Academia, Prague and SPB Academic Publishing bv, The Hague, 2: 613-618.

Sellnick, M. and K.-H. Forsslund (1953) Die Gattung Carabodes C. L. Koch 1836 in der schwedischen Bodenfauna (Acar. Oribat.). Arkiv für Zoology, 4: 367-390.

Subias, L. S. (2004) Listado sistematico, sinonimico y biogeografico de los Acaros Oribatidos (Acariformes, Oribatida) del mundo (Excepto fósiles). Graellsia, 60: 3-305 (updated on February 2014).

Weigmann, G. (2006) Hornmilben (Oribatida). Die Tierwelt Deutschlands, 76. Teil. Keltern: Goecke \& Evers, pp. 1-520.

Willmann, C. (1928) Die Oribatidenfauna nordwestdeutscher und einiger suddeutscher Moore. Abhandlungen Naturwissenschaftlicher Verein zu Bremen, 27: 143-176. 